\title{
Mühürdarzade Nuri Bey’in (Demirağ) Hayatı ve Çalışmaları (1886-1957)
}

\author{
Dr. Osman YALÇIN*
}

\begin{abstract}
ÖZET
Mühürdarzade Nuri Demiră̆, 1886 yllında Sivas Divriği'de doğmuştur. Babasını küçük yaşta kaybetmiştir. Öğrencilik hayatı oldukça başarıll geçen Küçük Nuri ailesinin geçimine katkıda bulunmak için 17 yaşında Ziraat Bankası'nda ișe başlamıştır.

Memuriyet hayatı dürüstlük ve halk faiz batağından kurtarmak için kollamakla geçmiştir. Meşrutiyetin ilanı ile Ziraat Bankası'nda çalışanlar ıslahat hareketlerinde görevlendirilmeye başlamıştır. Nuri Bey de bu kapsamda 1911 yılında İstanbul'da görevlendirilir. Burada görevinde hızla yükselir ancak işgal yıllarında memuriyetten ayrlarak ticarete atılır. Sigara kağıdı satar ve bununla yetinmeyip büyük ticari yatırımlara girer.

Cumhuriyet Döneminde devletin milli kaynaklarla demiryolu yapımı projesinde yer alır ve bu kapsamda $2012 \mathrm{~km}$. uzunlukta demir yolu ağ dösser. Türk Hava Kuvvetlerini güçlendirmek için halkın bağış kampanyasina para vererek birkaç uçak almakla sorunun çözülemeyeceğini değerlendirir. 1936 yılında Beşiktaş'ta Uçak Fabrikasını açar, bugünkü Yeşilköy Havaalanı'nın yerinde pilot yetiştirmek üzere okul açar. Türk Hava Kurumu kendisine 65 planör ve 10 uçak siparişi verir. Planörler teslim edilir ama uçaklar anlaşılmayan gerekçeler ile alınmaz ve Demiră̆ bundan büyük zarar eder. Yeni gelişstirdiği uçak projelerine Devlet Hava Yolları da ilgi göstermez. "Zafer uçakların kanatlarındadır" diye yola çıkar ama büyük idealleri maalesef anlaşılamaz. Demirağ' 'n girişimine yetkililer destek vermediği gibi malları haciz edilir. Bütün girişimleri sonuçsuz kalır.

Türkiye'de ilk muhalefet partisini kurar ama başarll olamaz. Demokrat Parti kontenjanından 1954 yılında bağımsız milletvekili seçilir. 1957 yılında Şeker hastalı̆ Indan vefat eder.
\end{abstract}

\footnotetext{
${ }^{*}$ Hava Kuvvetleri Komutanlığı, Tarihçe Subayı.
} 


\section{Nuri Demirağ, Biography and}

\section{Works}

\section{ABSTRACT}

Mühürdarzade Nuri was born in Sivas, Divriği in 1886. He lost his father at early age. After a bright studentship, young Nuri started working at Ziraat Bank (Bank of Agriculture) at the age of 17 to support his family.

His period of life in government duty was spent with honesty and protecting public against burden of interest rates. With the announcement of constitutional monarchy, employees of the Ziraat Bank were charged in reformist activities. Nuri Bey, in this extent, was assigned in Istanbul in 1911. He rapidly prometed in his career there but in the times of invasion he resigned and began his own career. First he started to sell the cigarette paper. He didn't satisfy in this bushess and then he established greater investments.

He attended the government's national funded railway project in the Republic Era and in this extent, he laid 2012 kilometers of railway. He found out that the problems related with establishment and improvement of the Turkish Air Force would not be resolved by buying a few aircraft with the local campaings. In 1936, he established an aircraft factory in Beşiktaş/İstanbul and a pilot school where Yeșilköy/İstanbul airfield is now located. Turkish Air Association ordered 65 gliders and 10 airplanes. Gliders were delivered but aircraft were not delivered with questionable reasons where Demirağ had significant loss of money. National Airlines didn't show interest in his new aircraft projects. He had started his career by saying "victory is in the wings of the aircraft", but unfortunately he was not understood. And supperted. Instead his properties were sequestrated. All his attempts were failed.

He founded the first opposition party in Turkey. But he failed. He was elected as an independent parliament member from Democrat Parti quota in 1954. He succumbed to diabetes in 1957.

\section{GíRiş}

19'uncu yüzyıldan itibaren Sanayii Devrimi ile birlikte Dünya'nın çehresi hızla değişmeye başlamıştır. "Dağları yerinden oynatan tabiat kuvvetleri sükûnet bulduğundan beri, hiçbir kuvvet dünyamızın yüzünü 
endüstri çağının tekniği kadar kuvvetle şekillendirmemiştirl"tespiti bu değişimin ifadesidir. $\mathrm{Bu}$ büyük değişimin yaşandığı zaman dilimi Türk milletinin ciddi sıkıntılarla boğuştuğu bir döneme rastlamış, sanayii alanında yaşanan hızlı gelişmelerin gerisinde kalmamak için önemli projeler geliştirilirmiş ancak istenilen sonuç alınamamıştır.

Birinci Dünya Savaşı'ndan yenik çıkan Osmanlı Devleti tarihe intikal etmiş, Türk milleti İstiklal Savaşı vererek, Türkiye Cumhuriyeti'ni kurma iradesini göstermiştir. Bir devrin hüzünlü batışına ve yeni bir devrin başlamasına tanık olan vatanperver insanlar Türk milletinin bir daha geçmişte yaşanan talihsizlikleri yaşamaması için gayret etmişlerdir. $\mathrm{Bu}$ insanlardan biri de pek çok girişiminin yanında demiryolu yapmakla ün kazanan daha sonra uçak fabrikası ve uçuş okulu açan Nuri Demirağ' ${ }^{\prime}{ }^{2}$.

\section{a. Nuri Demirăg'ın Hayatı}

Mühürdarzade Nuri (Nuri Demirağ) 1886 yılında Sivas Divriği'de doğmuştur. Divriği, Türklerin ilk yerleştikleri yerlerdendir. Divriği tarihi, sanat ve mimari tarzı ile Türklügün kendine has kültürünü barındırır. Mühürdarzade Nuri bu iklimin havasında yetişmiştir ${ }^{3}$. Divriği geçmişten günümüze coğrafik özelliği nedeniyle özel hususiyetleri olan bir yerdir. Mengücük Beyliği'nin Divriği kolundan ismini alan bu Türk beldesi özelliğini asırlardır titizlikle korumuştur ${ }^{4}$. Bu dönemde Anadolu'nun her tarafinda olduğu gibi burada da Ermeniler ticari hayata hakimdir. Mütegallibeler ve tefeciler tarafından bölgenin köklü aileleri borçlandırılmak suretiyle paraya hakim olanların insafına kalmışlardır. 1870'li yıllarda Divriği'yi ziyaret eden Fransız seyyah Burnaby da aynı yönde tespitlerde bulunmuştur ${ }^{5}$. Nuri Bey bu bölgenin şartları içinde doğmuş ve hayatı tanımaya başlamıştır.

Babası Ömer Bey, annesi Ayşe Hanım bölgenin soylu ve tanıdık ailelerine mensuptur. Aile, babanın memur maaşı ile geçinmektedir. 1889 yılında babası Ömer Bey vefat eder. Aile kendilerine tahsis edilen cüzi bir

\footnotetext{
${ }^{1}$ Tevfik Erdem (Edt.), Feodaliteden Küresellesmeve Temel Kavram ve Süreçler, Lotus Yay., Ankara, 2006, s.6; Osman Yalçın, Türk Hava Harp Sanayii Tarihi, G.Ü.Sos.Blm.Enst.,Basilmamış Doktora Tezi, Ankara, 2008, s.4

${ }^{2}$ Osman Yalçın, Türk Hava Kuvvetleri Teşkilatlanma Tarihi, G.Ü.Sos.Blm.Enst., Basılmamış Yüksek Lisans Tezi, Ankara, 2004, s.215,221

${ }^{3}$ M. Necmettin Deliorman, Nuri Demirağ'ın Hayat ve Mücadeleleri, Nu.D.Matbaas1, İstanbul, 1957,s.7; Ziya Şakir, Nuri Demiră̆ Kimdir?, Kanaat Matbaası, İstanbul, 1947, s.911. Fatih M. Dervişoğlu, Nuri Demirağ Türkiye’nin Havacılık Efsanesi, Ötüken Neş., İstanbul, 2007, s.19

${ }^{4}$ Şakir, a.g.e., s. 1,12

5 Şakir, a.g.e., s.22; Dervişoğlu, a.g.e., s.59-62
} 
maaş ile geçinmekte zorlanmaktadır. Anne Ayşe Hanım 5-6 dönümlük toprağı da işleyerek geçimini sağlamaya çalışmıştır ${ }^{6}$.

Nuri Bey çocukluğunda gösterdiği örnek tavırlarıyla dikkat çekmektedir. Annesinin hazırladığı azığı daha fakir olanlarla paylaşmakta, haksızlıklar karşısında doğru olanı çekinmeden söylemekte ve bu konularda oldukça hırçın davranışlar sergilemektedir. Arkadaşlarının kuş yuvalarını bozmalarına mani olacak kadar merhamet sahibi olan Mühürdarzade Nuri’nin eğitim hayatı örnek seviyededir? .

Nuri Bey, ailenin sıkıntısı nedeni ile küçük yaşta çalışmak zorunda kalmıştır. On yedi yaşında girmiş olduğu sınavı kazanmış ve Ziraat Bankası'nda memur olarak Kangal'da göreve başlamıştır. Nuri Bey memuriyette, 400 kuruş maaş almaktadır. Kendi ifadesine göre aldığı maaşın 200 kuruşunu annesine, 200 kuruşunu okuması için kardeşine gönderdiğini belirtmiştir .

Memuriyette ilk işine hemen adapte olmuş ve başarı sağlamıştır. Özellikle çiftçilere kolaylık göstermesi ve doğru bilgiler aktarması ile haklarının korunduğuna inanan çiftçiler tarafından aranan bir kişi olmuştur. Kredi batağına batan çiftçi ve esnafı uyarması ile adı duyulur. Meşrutiyetin

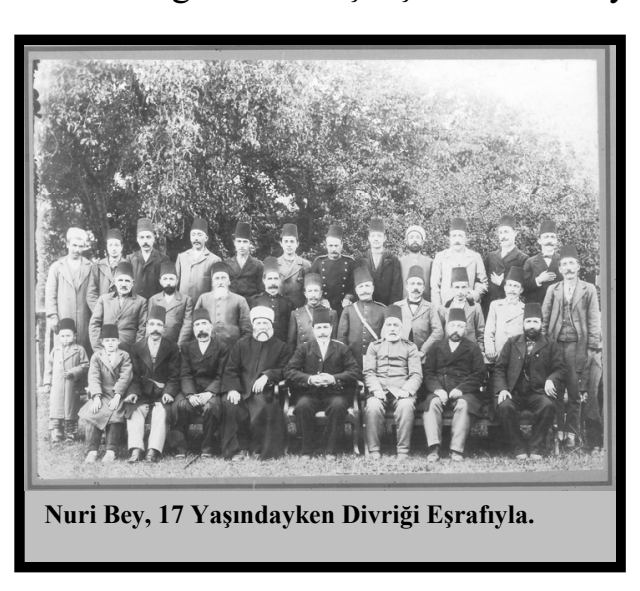

ilanı ile Ziraat Bankası'nda çalışanlar, 1slahat hareketlerinde görevlendirilmeye başlamıştır. Nuri Bey de bu kapsamda 1911 yılında İstanbul'da daha iyi bir vazifeyle görevlendirilmiştir?.

İstanbul'da ilk görev yeri Hasköy Mal Müdürlüğ̈̈'dür. Burada başladı̆̆ 1 yeni görevinde ülkenin içine düştüğü mali kırtasiyeciliğin korkunç tablosunu, yönetime yakın olanların şirin görünmek için yaptıkları riyakarlığı gömüş ve ülkenin sona doğru giden acı haline şahit olmuştur. Çalışmalarında ciddidir ve mesaisini tam yaparak, İstanbul'da bulunduğu süre içerisinde mesleki bilgisini geliştirmek için Darülfünun'da verilen konferansları takip etmiştir. Tarih, edebiyat ve felsefe alanında dersler alarak

${ }^{6}$ Şakir, a.g.e., s.12-15; M. Bahattin Adıgüzel, Türk Havacıllğında İz Bırakanlar, THK Kültür Yay. No:7, Ankara, 2006, s.120,121; Dervişoğlu, a.g.e.,., s.59.

Sakir, a.g.e., s. 15

8 Dervişoğlu, a.g.e., s.73

${ }^{9}$ Şakir, a.g.e., s.24-26 
kendini yetiştirmeye gayret etmiştir. Buradaki çalışmaları dikkat çekmiş ve mesleki hayatının sekizinci yılında "Maliye Şubeleri Müfettişliği" görevine yükselmiştir ${ }^{10}$. İstanbul'daki görevleri ve görev yerleri kronolojik olarak şöyledir:

a) 11 Mayıs 1911 Hasköy Mal Müdürlüğü Refikliği,

b) 1 Eylül 1911 Beyoğlu Muhasebe Tahsilat Tetkik Memurluğu,

c) 12 Nisan 1912 Varidat Muamelat Katipliğii,

ç) 1 Eylül 1913 Beyoğlu Muhasebesi 2'inci Şube Başkatipliği,

d) 3 Haziran 1914 Tophane Tahsil Şubesi Memurluğu,

e) 8 Temmuz 1914 Beşiktaş Varidat Tahakkuk Memuru,

f) 18 Nisan 1918 İstanbul Vilayeti Varidat Mümeyyizi,

g) 23 Nisan 1919 Bandrol Başmemuru,

g) 10 Haziran 1920 İstanbul Vilayeti Tahakkuk Müfettişi,

h) 10 Ekim 1920 Memuriyetten istifa etmiştir ${ }^{11}$.

Memuriyette hızla yükselmiş ve o günün şartlarında iyi bir mevkiye gelmiştir. Nuri Bey, etkili bir konuma geldiğinde memuriyetten istifa etmiştir. Bunun nedeni; o dönemde İstanbul işgal altında olduğu için özellikle gayri müslimlerin yoğun olarak yaşadığı Beyoğlu ve Galata gibi semtler Türkler açısından tehlikelidir. Nuri Bey, memuriyeti sırasında işi gereği Kurtuluş'da bulunan Maliye Şubesine uğramak durumunda kalmış, buradan ayrılırken beş on palikarya tarafından başındaki fes alınmış ve yere atılıp çiğnenmiştir. $\mathrm{Bu}$ onur kırıcı hadise karşısında; "Milli haysiyet ve şerefi, üç buçuk palikaryanın ayakları altında çiğnenen bir hükümete memurluk edemem " diyerek memuriyetten istifa etmiştir ${ }^{12}$.

Memuriyetten ayrıldığında bütün serveti 56 Türk altınıdır. Bu altınları paraya çevirir ve 256 Türk Lirası ile iş kurmaya karar verir. Amacı 256 lirayı on yılda bir milyon lira yapmaktır. Ticari hayata o dönemde gayri müslimlerin denetiminde bulunan ve iyi para getirdiğini tespit ettiği sigara kağıdı imali ile başlamışıtır ${ }^{13}$. Üretimini yaptığı sigara kağıdının adına da "Türk Zaferi Sigara Kağıdl”" adını vermiştir. İşgal altında bulunan bir yerde isim oldukça çarpıcıdır. Sigara kağıdı tekelinin her gün Türklere türlü türlü

\footnotetext{
${ }^{10}$ Dervişoğlu, a.g.e., s.65-67

${ }_{11}^{11}$ Dervişoğlu, a.g.e.,., s.66

${ }^{12}$ Deliorman, a.g.e., s.9; Şakir, a.g.e., s.38; Dervişoğlu, a.g.e., s.67; Adıgüzel, Türk Havacılığında İz., s.124

${ }^{13}$ Şakir, a.g.e., s.5
} 
eziyetler eden gayri müslimlerde olması Nuri Demirağ'ın yeni işinin tutmasında etkili olmuştur ${ }^{14}$. Ketencilerde açtığı işyerinin iç duvarına "Satış peşin...fiyat maktu...pazarlık yok" yazmıştır. Bu üç kural Nuri Demirağ'ın ticaret anlayışının temeli olmuştur. Sigara kağıdı imali, Tütün İnhisarı İdaresi'ne devredildiğinden bu alandan çekilmek zorunda kalmış ve 1920 yılında, "Mühürdarzade Kantariye İthalat-Ihracat Tütün Gümrüğ̈̈ Şirketi" adıyla yeni bir iş yeri açmıştır. Nuri Bey, İstiklal Harbi sonunda 84.000 TL. servetle hatırı sayılır bir işadamıdır ${ }^{15}$.

Türk ticaret hayatında 2'nci Meşrutiyet Dönemi ile birlikte değişimler başlamış, nasıl Türk Milliyetçiliği azınlıklar karşısında reaksiyonel bir değişim ise ticari sahada da Türklerin ticari hayata girmesi mevcut gayri müslim tekeline karşı bir reaksiyonel hareket olarak gelişmiştir ${ }^{16}$. Başta İttihat ve Terakki Partisi yöneticileri olmak üzere dönemin yetkili kişileri Türklerin ticari hayatta söz sahibi olmasını istemektedir. Devletin yetkilileri, son yıllarda Osmanlı Devleti'nin aleyhine faaliyet gösteren bir takım çalışmalar karşısında acı gerçeklerle yüzleşerek tedbir almak zorunda kalmışlardır.

Türklerin ticari hayatta etkin olması için teşvik edilmesi Cumhuriyet Dönemi'nde de devam etmiştir. Nitekim daha Cumhuriyet ilan edilmeden İzmir İktisat Kongresi ile bu konudaki hassasiyet ortaya konmuş, Lozan Barış Antlaşması ile Türkiye dünyada bağımsız bir ülke olarak yerini almıştır. Ancak Türkiye, harap ve dünyanın en yoksul memleketlerinden biridir. Bu şartlar altında en büyük sıkıntının bayındırlık sorunu olduğundan hareketle öncelik ulaşım sahasına verilmiştir. 1924 tarihinde çıkarılan 449 sayılı kanunla Samsun-Sivas Demiryolu ihaleye verilmiş, yeni düzende yerli teşebbüsün önünün açılması ve yabanc1 tekelinde olan büyük ihalelere Türklerin de katılması günün önemli bir gelişmesi olmuştur.

Nuri Demirağ ihalenin ilk 7 km.lik kısmını 210.000 TL'ye almıştır. Hatıratında yabancı firmalara göre oldukça uygun şartlarda ihale almasına rağmen buradan çok para kazandığını belirtmektedir ${ }^{17}$. Bu başarılı sonuçtan sonra demiryolu yapımı Demirağ'ın yeni çalışma alanı olmuştur. Yaptığı demiryolu toplamı 1012,5 kilometreyi bulmuştur. Bugün Türkiye'de bulunan her sekiz kilometre demiryolundan yaklaşık bir kilometresini Demirağ inşaa etmiştir. Demirağ soyadı bu sahadaki çalışmaları sebebiyle Atatürk

\footnotetext{
${ }^{14}$ Şakir, a.g.e., s. 42,43

${ }^{15}$ Deliorman, a.g.e., s.11; Sakir, a.g.e., s.83; Deliorman, a.g.e., s.72-75

${ }^{16}$ Karluk, a.g.e., s.193; Oran, a.g.e., s.49-51; Soner Yalçin, Efendi-Beyaz Türklerin Büyük Sırrı, 5. Bsk., İstanbul, 2004, s.225-229

${ }^{17}$ Dervişoğlu, a.g.e., s.70-73; Adıgüzel, Türk Havacılığında İz., s.124,125; Deliorman, a.g.e., s. 15
} 
tarafindan verilmiștir. Cumhuriyetin Onuncu yılında bestelenen ve gururla söylenen; "Demirağlarla ördük Anayurdu dört baştan... Türk'e durmak yaraşmaz; Türk önde, Türk ileri" dizeleri kısa sürede yapılan büyük işlerin coşkulu ifadesidir. Aradan geçen uzun zamana rağmen 10’uncu Y1l Marşı bu gün de toplumu etkilemeye devam etmektedir. Cumhuriyet'in ilk yıllarında varolma ve yeni bir devlete sahip olmanın coşkusu hemen bütün insanlarda görülmektedir.

Nuri Demirağ'ın yaptığı demiryolu ve faaliyet alanları arasında en önemli girişimleri ${ }^{18}$,:

a) Samsun-Sivas Hatt1

b) Fevzipaşa-Diyarbakır Hattı,

c) Afyon-Antalya Hatt1,

ç) Sivas-Erzurum Hatt1,

d) Irmak-Filyos Hatt1,

e) Bursa'da Merinos Fabrikası'nın İnşası,

f) Karabük Demir-Çelik Fabrikasının bir kısmı,

g) İzmit Selüloz Fabrikası,

$\breve{g})$ İstanbul Hal Binas1,

h) Eceabat-Havza Şosesi,

1) Birçok hayrat çeşme yapımı.

Nuri Demirağ'ın daha sonra hayatında en önemli uğraşı alanı havacılık olmuştur. Nuri Demirağ'ın hayatında üç husus dikkati çekmektedir. Bunlar; işadamı, dava adamı ve siyaset adamlığıdır ${ }^{19}$. Yetiştiği Divriği kültüründe Türk milletinin köklü ve mütevazi kültürünü özümsemiştir. O günün toplum yapısını değerlendirmek gerekirse, bir tarafta, Türk olmayan, cephelerde savaşmayan, aile bütünlüğü kesintiye uğramayan, Batılı devletlerce en ufak bir hadisede desteklenen bir sosyal yapı vardır. Diğer taraftan devletin kurucusu ve sahibi olmasına rağmen; horlanan ve vergiler altında ezilen Türkler bulunmaktaydı. Türkler, savaşlarda hayatını kaybetmekte, hemen her aile belli zamanlarda kırılmalar yaşamaktaydı. On milyonlarca kilometre karelik alanı savunmak zorunda kalan Türk insanı, önemli problemlerle ve sorunlarla bütünleşik hayatı yaşamak durumundaydı.

\footnotetext{
${ }^{18}$ Deliorman, a.g.e., s.81-88

${ }^{19}$ Dervişoğlu, a.g.e., s74; Adıgüzel, Türk Havacılı̆̆ında İz., s.124-126
} 
Türk toplumu, zengin komşuları olan Ermeni ve Rumların insafına kalmış ve ortalama 200 yıl devam eden sosyal yap1, bütün ağırlığı ile yirminci asrın başına kadar varlığını sürdürmüştür. Bu yapı ülkenin hemen her tarafında bir birine yakın özellikte devam etmiştir. Nuri Bey, İstanbul'da göreve başladığı zaman sosyal dengesizliğin ve adil olmayan yapının burada daha büyük boyutta yaşandığına bizzat şahit olmuştur. Mevcut tablo karşısında çözümün, iktisaden güçlü, idealist ve inisiyatifi millet adına kullanan bir düzenden geçtiğini gören ve yılmadan çalışan ender kişilerden birisi de Nuri Demirağ olmuştur. Nuri Bey'e göre çok para kazanmakla, kazanılan paranın doğru sahalarda harcanması çok farklıdır. Nuri Bey, bürokrat veya devleti idare makamında yetkili siyasetci değildi. O, ticaret yapan, para kazanan ve çalışma sahası olarak Türkiye'nin kalkınmasına destek olacak alanı yatırım sahası olarak seçen bir girişimciydi.

Nuri Demirağ'in ülke sorunlarını aşmak için tasavvur ettiği çözüm yolları ile Atatürk'ün çözüm metotları arasında büyük ölçüde paralellik olduğu görülür. $\mathrm{Bu}$ anlamda eksikliği hissedilen önemli bir ilgi alanı da hava sanayiinde yapılması gereken işler olmuştur.

Nuri Bey, yeni kurulan Türkiye Cumhuriyeti'nin zayıf düşmemesi için milletin zenginlerine daha çok görev düştüğüne inanmaktadır. Havacılık sanayii bu gün olduğu gibi, o günlerde de önemli yatırım gerektirmekteydi. Nuri Bey oldukça yüksek meblağda bir birikime sahipti. 1936 yılına Türkiye bütçesi 212 milyon lirayken onun servetinin 11 milyon lira olduğu dikkate alınırsa ${ }^{20}$ yıllık Türkiye bütçesinin yaklaşık \% 5'i kadar bir servete sahiptir. Hatta bir dönem "Nuri Demirağ kadar zengin" sözü meşhur olmuştur. Ancak zenginliği haklı ve meşru kaynaklara dayanmaktadır. Yazar Şakir Ziya'ya göre, Demirağ' in zenginliği harp zenginliği değildir. Talih oyunları ile zengin olmamış, kirli işlere asla girmemiştir. Bütün servetini ölçülü ve hesaplı hareketlerle temin etmiştir. Milletten aldığını yine milletin menfaatine harcamanın doğru olduğuna inanmıştır ${ }^{21}$.

Nuri Bey’i, dava adamı yapan para kazanması değil, ülkenin menfaatine yatırım yapma erdemliliğini göstermesidir. Nuri Bey, dünyadaki gelişmeleri ve olası çatışmaları önceden görmüş ve Türkiye'nin acilen ihtiyaç duyduğu bir alan olan havacılığa katkıda bulunmak için çalışmaya başlamıştır. Havacılık tarihinde önemli bir yeri olan Nuri Bey, Türkiye'de özel sektörde ilk uçak fabrikasını kurmuş, uçak ve planör üretmiştir.

\footnotetext{
${ }^{20}$ Dervişoğlu, a.g.e., s.91

${ }^{21}$ Şakir, a.g.e., s.4
} 


\section{b. Beşiktaş Nuri Demirağ Uçak Fabrikası}

16 Şubat 1925 tarihinde Gazi Mustafa Kemal tarafindan Türk Tayyare Cemiyeti'nin ${ }^{22}$ aç1lışı yapılmıştır. Aç1lışta "İstikbal göklerdedir. ${ }^{23}$ ", sözünü söyleyen Mustafa Kemal Paşa, havacılığın önemini görmektedir. Türkiye'nin geleceğinin ve bağımsızlığının teminatı olarak görülen hava gücüne ve sanayiine önem verilmektedir ${ }^{24}$. Türk Tayyare Cemiyeti kuruluş tarihinden itibaren hava gücünün geliştirilmesi, güçlendirilmesi için çalışmaya başlamıştır. Ülkenin o yıllarda gelir kaynaklarının sınırlı olması ve hemen her alanda önemli sorunları olması nedeniyle havacılığın geliştirilmesinde halkın bağışlarına müracaat edilmiştir.

Bağış toplamak ve halka ulaşabilmek için geniş kapsamlı bir tanıtım çalışması yapılmıştır. Nitekim Türk Hava Kurumu Başkanı Cevat Abbas'ın Genel Başkan olduğu dönemde başlayan bu süreç, Fuat Bulca zamanında devam etmiştir. $\mathrm{Bu}$ alanda yapılan çalışmalar neticesi Türk Hava Kurumu onbeş yıllık süre içinde ianeler vasıtasıyla elde ettiği 72 milyon lira gelirin 54 milyon lirasını Türk Hava Kuvvetleri bütçesine aktarmışıır ${ }^{25}$. Aktarılan bağışlar ile 350 civarında uçak alınmış ve Türk Hava Ordusu'na bağışlanmıştır ${ }^{26}$.

Nuri Bey'e yaptığı demiryolundan dolayı "Demiră̆" soyadını veren Atatürk'ün en önemli önceliklerinden biri de Türk göklerinin Türk imali uçaklarla Türk gençliği tarafından korunmasıdır. Türk Tayyare Cemiyeti’nin kurulmasina öncü olan Atatürk, 1935 tarihinde Türk Hava Kurumu'na 10.000 lira bağ $1 s ̧ t a$ bulunarak, bu kurumun önemine dikkat çekmiştir. Yine aynı dönemde Nuri Demirağ'ın kardeşi Naci Demirağ, Başbakan İsmet İnönü'ye bir telgraf çekmiş ve Hava Kuvvetleri için 1-3 uçak alacak şekilde 100.000-120.000 Türk Lirası yardımda (iane) bulunmak istediğini bildirmiştir. Başbakan İnönü’nün Naci Demirağ’a teşekkür cevabı dönemin gazetelerinde yer almıştır. Yine aynı kampanya kapsamında Vehbi Koç da 5000 Türk Lirası bağışta bulunarak uçak alım kampanyasına destek olmuştur. $\mathrm{Bu}$ dönemde bir uçağın bedeli yaklaşık 35.000-40.000 lira civarındadır.

22 Türk Tayyare Cemiyeti adı 3 Mayıs 1935 tarihinde Türk Hava Kurumu olarak değiştirilir.

${ }^{23}$ Atatürkçülük Atatürk'ün Görüş ve Direktifleri Birinci Kitap, Gnkur.Bsm., Ankara, 1983, s. 200; 16; Şubat 1925 Türk Tayyare Cemiyeti’nin Açılısında Söylenmiştir.

${ }^{24}$ Nitekim havacilık alanında devletin girișimleri sürecek ve 15 Ağustos 1925 tarihinde Kayseri'de Türkiye ile Alman Junkers Firması arasında bir uçak fabrikası açılması için antlaşma yapılır. 6 Ekim 1926 tarihinde resmi açılışı yapılır.

${ }^{25}$ Oktay Verel, İstikbal Göklerin Gökler Bizimdir Birinci Cilt, Türk Hava Kurumu Yayınlari 3, Istanbul, 1985, s.17-21

${ }^{26}$ Kaymakl1, a.g.e., s.253, 329 


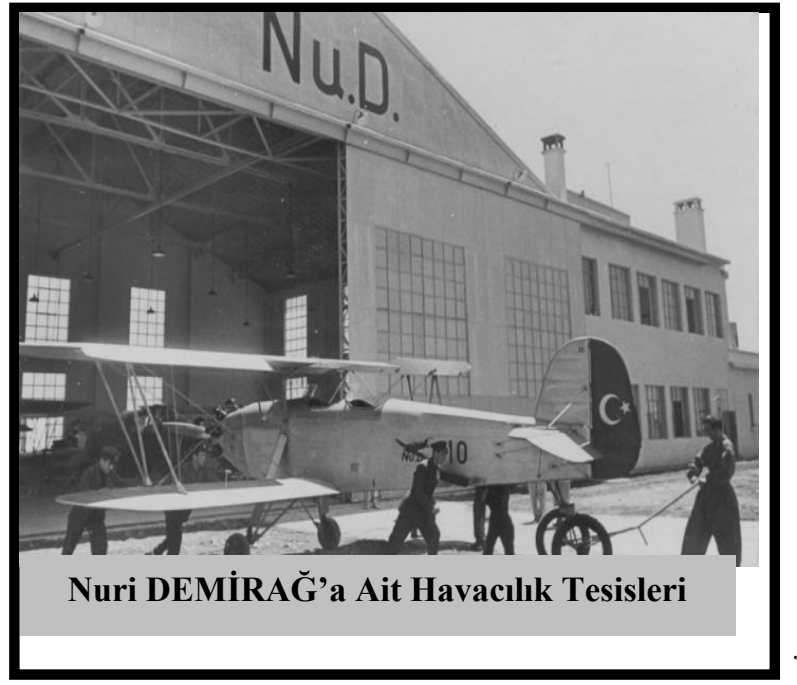
Nuri Demirağ'a bağış kampanyasına destek olup olmayacağ 1 sorulduğunda cevabi: "Siz ne diyorsunuz? Benden bu millet için bir şey istiyorsaniz, en mükemmelini istemeli- siniz. Madem ki bir millet tayyaresiz yaşaya- maz, öyleyse bu yaşama vasitasinı başkalarının lütfundan beklememeli- yiz. Ben bu uçakların fabrikasinı yapmaya talibim $^{27}$ " olmuștur.

Nuri Demirağ, Hava Harp Sanayiinde; uçakları dışarıdan satın almak ve dışarının bağımlısı olmak yerine Türk tasarımı uçakların Türk semalarına hakim olmasını isteyen bir girişimcidir. Yabancı lisanslarla uçak üretmenin taklitçilikten öte bir şey olmadığına inanmaktadır. Çünkü uçak üretim lisansını satan ülke, demode olmuş, kendisi için tehdit olmayacak ve ekonomik ömrü olmayan sistemlerin satışına müsaade etmesi, öncelikle kendi güveliği ve ülke çıkarları gereğidir. Nuri Demirağ bunun farkında olduğu için Türk tasarımı uçağın imalinin gereğine inanmaktadır. Diğer taraftan Nuri Bey, oldukça yüksek meblağlı yatırım yapabilecek imkana sahip bir işadamıdır.

Uçak üretmenin zor ve pahalı bir iş olduğunun farkındadır. Yanına kendisi gibi düşünen ve Türk tasarımı uçak üretimine destek veren Uçak Mühendisi Selahaddin Alan'ı ortak alarak almıştır. Avrupa seyahatinde, Alman Sivil Hava Federasyonu aracılığ 1 ile beş Alman tayyare mühendisini, atölyesinde istihdam etmiştir. Uçak sanayii alanında uluslar arası alanda önemli bir isim olan Prof. Gasner ile de bir anlaşma yapılmıştır. 1930'ların ortalarında, dünya yeni bir gerginliğe doğru süratle yol almaktadır. Avrupa ülkeleri hava harp sanayii alanında hızlı bir yarışın içine girmiştir. Batılı gelişmiş devletler özel sektörü her türlü ekonomik sıkıntıya rağmen mutlak olarak desteklemektedir. Nuri Bey, Batı ülkelerindeki gelişmeleri çok iyi yorumlamış ve Türkiye'de de böyle bir tesisin varlığının zorunlu olduğuna inanmıştır.

\footnotetext{
${ }^{27}$ Dervișoğlu, a.g.e., s. 90
} 
Nuri Demirağ tarafindan kurulan fabrika ve eklerinin tamamlanmasi kolay olmamıştır. Nuri Demirăg, Hava Müsteşarlığı'ndan uçak fabrikası için gerekli olan ve yurt dışından ithali yapılacak olan malzemelerin teminine müsaade edilmesini talep etmiştir. Hava Müsteşarlığı'nın Başbakanlığa yazısı, Başbakanlığın Maliye Bakanlığı vasıtasıyla Milli Savunma Bakanlığı'na cevabının yer aldığı arşiv belgesine göre; Yeşilköy'de kurulan uçak stok, montaj ve tamir atölyesi için gerekli olan malzeme ve makinelerin yurt içinden tedariki yapılamadığından Amerika'dan temini gerekmektedir. İkili anlaşmalar gereği yapılacak ithalatın belli bir ihracata karşılık yapılması zorunludur. Bunun sağlanması için mevcut uygulamaya göre ithalat talebinde bulunanların talepleri müracaat sırasına göre işleme alınıyordu. Nuri Demirağ'ın talebi mevzuat gereği zamanında gerçekleşmemiştir. Konu ile ilgili arşiv belgelerinde belirtildiğine göre ihtiyaç duyulan malzeme ve makinelerin başka bir ülkeden temini de mümkün değildir ${ }^{28}$. Şüphesiz ticari ilişkilerin belli kaide ve usulleri olması kaçınılmazdır. Ancak ülke için hayati öneme haiz olan uçak fabrikasının taleplerinin de sıradan bir ithalat olarak değerlendirilmesi oldukça düşündürücüdür.

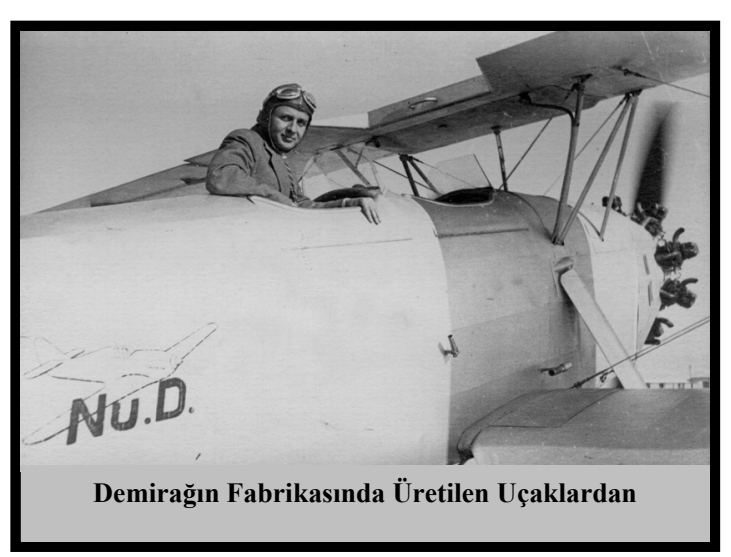

Nuri Demirăg, 17 Eylül 1936 tarihinde havacilık sanayiinin ilk temellerini atmaya başlamıştır. 10 yıllık devreyi kapsayan bir planprogram hazırlatır. $\mathrm{Bu}$ program gereği, bugün Deniz Müzesi olan Beşiktaş Barbaros Hayrettin İskelesi'nin yanında Tayyare Etüt Atölyesi kurmuş ${ }^{29}$ ve burada kurduğu tayyare atölyesini kısa sürede büyük bir uçak fabrikası haline getirmiştir.

Beşiktaş'daki etüt atölyesini kurduğu yıl Divriği'de; “Büyük Gök Okulu”nun temelini atmıştır. Nuri Demirağ'ın girişimini destekleyen dönemin iki önemli ismi, Genelkurmay Başkanı Mareşal Fevzi Çakmak ile Hava Müsteşarı Zeki Doğan olmuştur. Mareşal Fevzi Çakmak, 6 Temmuz 1936 'da Nuri Demirağ ve hükümete yazdığı yazılarla, Zeki Doğan ise 4

${ }_{28}^{28} B C A$, Tarih 27.11.1939, Dosya: 25712, Fon Kodu: 030.10, Yer No: 212.441 .12

${ }^{29}$ BCA, Tarih 28.6.1948, Dosya: 6380, Fon Kodu: 030.10, Yer No: 61.413 .34 
Ağustos 1938 'de yazdığı kutlama yazısı ile kurulmakta olan hava harp sanayiine destek çıkmışlardır. Kuruluşu aşamasında Türk Hava Kurumu tarafindan 10 adet uçak ve 65 adet planör siparişi verilmiştir. Yine Milli Savunma Bakanlığı 16 Haziran 1942 tarihinde yazdığı yazıyla Hava Kuvvetleri'ne ait tayyare, motor ve kara nakil vasitalarının tamir ve bazı yedek parçalarının temininin Demirağ'a ait tesislerde yapılmasını Bakanlar Kurulu'na tavsiye etmiştir. 1 Ağustos 1942 tarihinde Bakanlar Kurulu mezkur talebi kabul etmiştir ${ }^{30} .1949$ yılına kadar Hava Kuvvetleri Komutanlığı'nın uçaklarının bir kısım onarım ve malzeme ihtiyacı desteği Demirağ' $1 n$ tesislerinden karşılanmıştır. Milli Savunma Bakanlığı'nın teklifi ile Demirağ Uçak Fabrikası'nın harp sanayii statüsü Bakanlar Kurulu kararı ile 11 Haziran 1949 tarihinde sona ermiştir.

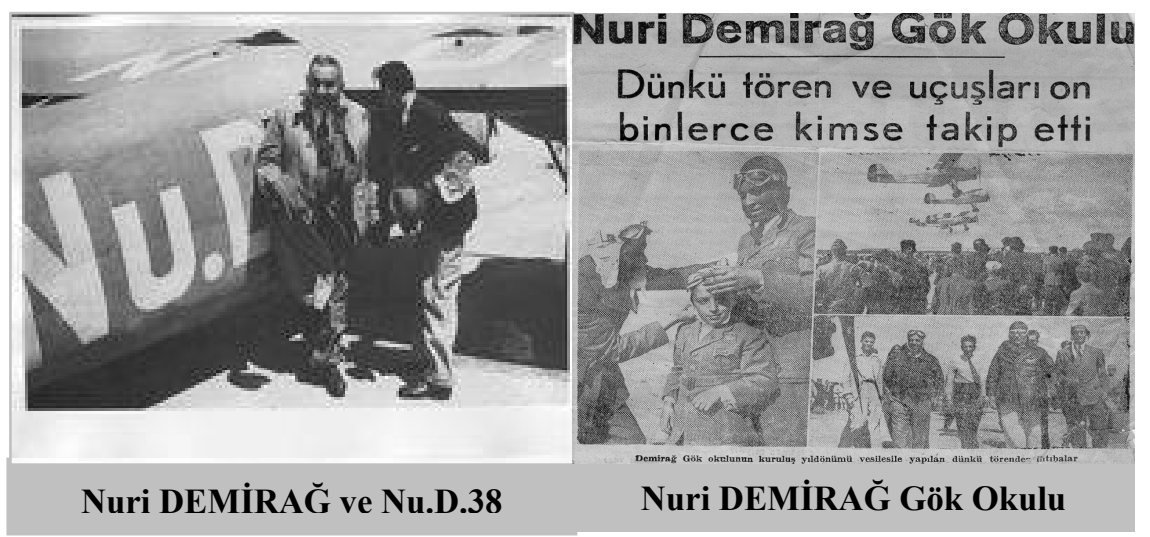

İlk yerli yolcu uçağı, Beşiktaş Demirağ Uçak Fabrikasında imal edilmiştir $^{31}$. İstanbul Beşiktaş Uçak Fabrikası'nda yapılan ilk yerli Türk uçağı, 1941 yılı Ağustos ayında Nuri Bey'in doğduğu yer olan Divriği'ye uçarak gidip gelmiştir. Halkı heyecanlandıran bu tür gösterilerin yararlı olduğunu düşünen Nuri Bey, Eylül ayında 12 uçaklık bir filoyu, Bursa, Kütahya, Eskişehir, Ankara, Konya, Adana, Elazı̆̆ ve Malatya rotasında uçurarak Türk halkına, Türk yapımı uçaklarla Türk semalarının korunabileceğini göstermek ve halka güven vermek istemiştir.

İkinci Dünya Savaşı'nın devam ettiği yıllarda yetkili makamlar tarafından, fabrikanın kapasitesi ile ilgili bilgi istenmiştir. Cevap olarak yıllık, 300 mektep veya 150 eğitim ya da 50 avc1 uçağının yapılabileceği

\footnotetext{
${ }^{30}$ Dervişoğlu, a.g.e., s.95

${ }^{31}$ Şakir, a.g.e., s.140
} 
bilgisi iletilmiştir 32. Yeșilköy'de 1500 dönümlük arazi üzerinde "Gök Stadyumu" adında ilk sivil hava meydanını faaliyete geçirmek için Elmas Paşa Çiftliğini satın almıştır ${ }^{33}$. O sıralar Avrupa'nın en modern havaalanı olan Amsterdam'daki havaalanı benzeri, 1000x1300 metre boyutlarında düz bir tayyare alanı yaptırmıştır.

Elmas Paşa Çiftliğinde kurulan okul çok gelişmiş bir sisteme sahiptir. Okul bünyesinde; hangarlar, atölyeler ve Gök Okulu kurularak uçak üretimi ve havacılık eğitimi başlatılır. Gök Okulu'nda iki farklı eğitim verilmektedir. Bunlardan biri; pilot yetiştirmeye diğeri ise uçakların bakımını ve teknik desteğini sağlayacak personelin yetiştirilmesi yöneliktir. Nuri Demiră̆, Yeşilköy Gök Okulu için öğrenci kaynağını ise ortaokul seviyesindeki Divriği Gök Okulu'ndan mezun olan ve yetenekli olduğu görülen öğrencilerle, İstanbul'daki üniversite öğrencilerinden karşılamay1 planlamıştır ${ }^{34}$.

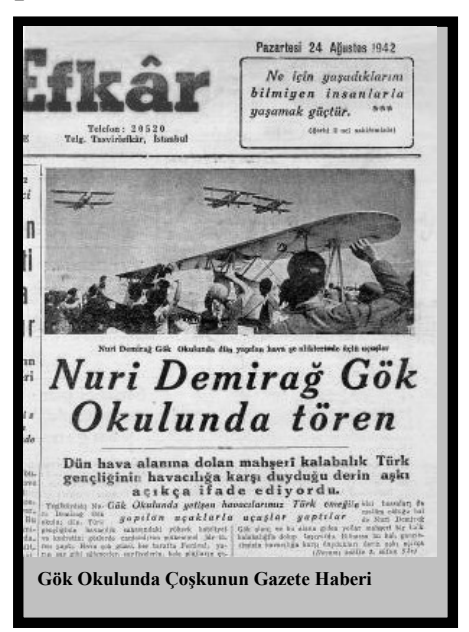

İkinci Cumhurbaşkanı İsmet İnönü'nün oğlu Ömer İnönü de Nuri Demirağ'ın Gök Okulu'nda eğitim almaya başlamış ancak daha sonra eğitimine Türk Hava Kurumu'na bağl1 Türk Kuşu'nda devam etmiştir ${ }^{35}$. Ömer İnönü'nün bu kararında, Nuri Demirağ'ın uçuş okuluna yönelik bazı olumsuz tavirların seslendirilmesinin sebep olduğu sanılmaktadır.

Nuri Demirağ' 1 önemli bir ideali de, Türk semalarını koruyacak olan havacılığa gönüllü bir gençliğin yetişmesidir. Gençlerin yetenekli ve korkusuz birer pilot olabilmeleri için çalışmalar yapılmıştır. Kaynaklarda rakamlar farklı geçmekle birlikte Gök Okulunda yaklaş1k 32.000 sorti uçuş yapılmıştır. Burada yetişen pilot sayısı 290 kişiyi bulmuştur. Nuri Demirağ, büyük yatırımlarla kurmuş olduğu Gök Okulu'nda yalnız uçucu yetiştirmez, aynı zamanda prensip sahibi bir neslin yetişmesi için gayret eder.

\footnotetext{
${ }^{32} B C A$, Tarih 29.11.1939, Dosya: 6158, Fon Kodu: 030.10, Yer No: 59.399.25; Deliorman, a.g.e., s. 35

${ }^{33}$ Deliorman, a.g.e., s.35

D Dervişoğlu, a.g.e., s.95,96; Hürkuş, a.g.e., s.324

${ }^{35}$ Deliorman, a.g.e., s. 33

Açılkama: Ömer İnönü'nün eğitimine Türk Kuşu'nda devam etmesinin nedeni Demirağ Gök Okulu hakkında yapılan olumsuz propagandalardır.
} 
Nuri Demirağ, Gök Okulunda, milli ve manevi değerlere önem vermiştir. Nuri Demirağ'a göre; Cumhuriyete, vatana, millete, milli kültürüne ve manevi değerlerine bağlı bir havacı gençlik göklerde amansız düşmanlar karşısında, kendinde güç bulacaktır. Bu nedenle uçucu gençliğin içtiği andında ${ }^{36}$ belirtildiği gibi, Türk milletinin birlik ve dirliğine bağl1, ülkenin değerlerine inanan dinamik bir güç olması amaçlanmıştır. Nuri Demirağ Gök Okulu'nun öğrencilerine tenbihlediği altı prensip; İsretten, oyundan, iffetsizlikten, ĕgrilikten, tembellikten ve zulümkarliktan sakınmalarıdır ${ }^{37}$.

Nuri Demirağ'a göre; Batının yaptığı herşeyi Türk de üretebilir ve yapabilir. Zafer artık süngünün ucunda değil uçakların kanadındadır. Havacılığa verdiği önemin en büyük nedeni bu gerçeği görmüş olmasıdır ${ }^{38}$.

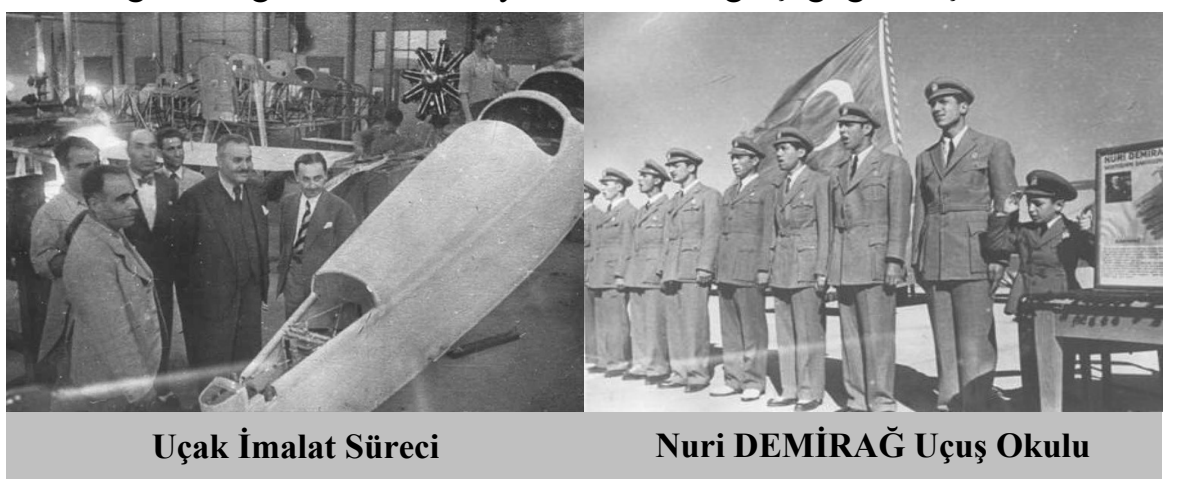

Nuri Demirağ, Türkiye'de ilk paraşüt üretim merkezini kuran girişimci olmuştur. Paraşütün ipekten yapılması sebebiyle Üsküdar'da satın aldığ Hüseyin Avni Paşa korusunda dut ağacı ve ipek böceği yetiştirmek için girişimde bulunmuş ${ }^{39}$ ve ilk paraşüt imalatını gerçekleştirmiştir

Nuri Demirağ'ın dönemine göre oldukça ileri sayılan faaliyeti Sivas ve İstanbul gazetelerinde akis bulur ve halka duyurulur. Çalışmalarına bazı

${ }^{36}$ Dervişoğlu, a.g.e., s.97 Demirağ Uçuş Okulu'nun Yemini: "Bu altı kanatta yazılı altı nevi fenalığ 1 (İsretten, Oyundan, iffetsizlikten, eğrilikten, tenbellikten ve zulümkarlıktan) havada, karada ve denizde yapmayacağıma, yapanları gücümün yettiği, dilimin döndüğü kadar uğraşarak yaptırmamaya çalışacağıma namusum, vicdanım, şerfim, varlığım, benliğim hulasa, vatanım ve öz Türklüğüm namına and içiyorum. Ömrüm oldukça bu sayılı fenalıklardan herhangi birini işlersem ve başkalarının fenalıklarını da usanmadan, asla fütur getirmeden telkin ve tatlılıkla men'e çalışmazsam gökler başıma yıkılsın, dağlar beni ezsin, 1rmaklar ve denizler beni boğsun. Hasılı her türlü felaket beni yok etsin.” Deliorman, a.g.e., s. 24

${ }^{37}$ Deliorman, s.24; Dervișoğlu, a.g.e., s. 100

38 Deliorman, a.g.e., s.25; Şakir, a.g.e., s.92-94; Adıüzel, Türk Havacılı̆̆ında İz., s.137

${ }^{39}$ Dervişoğlu, a.g.e., s. 103 
olumsuz gelişmelere rağmen basında yer verilmesi dönemin şartları içinde olumlu bir gelişmedir ${ }^{40}$.

Nuri Demirağ'ın girişimiyle 17 Ağustos 1941'de ilk "Havacllı Bayramı" kutlanmıştır ${ }^{1}$. 17 Ağustos 1941 tarihinde Tasvir-i Efkar Gazetesi'nin muhabiri Kandemir'in "Bu fabrikayı nasıl kurdunuz?" sorusuna cevab1, "İstikbalimizin, istiklalimizin, şerefimizin göklerde olduğuna iman ettikten sonra, 5-6 sene bilfasila yanıma mütehassis gençleri de alarak Moskova'dan tut, ta Londra'ya kadar uğrayıp uzun uzadiya tetkikler yapmadığımız yer kalmadı. Avrupa'nın bütün tayyare fabrikalarını, havacılık müesseselerini geceli gündüzlü dolaştık. Neticede her yerde gördüklerimizin içinden en mükemmellerini seçerek burayı kurduk" olmuştur. Aynı mülakatın devamında Kandemir'in, "Gelecekteki tasavvurlarını nelerdir?" sorusuna ise: "Evvela bu müesseseyi fevkalade genişletmek, bir milyon iki yüz bin liraya mal olacak büyük Yeşilköy Gök Lisesini kurmak...Divriği'de binlerce genci sinesine alacak; telsizciliği, motorculuğu, pilotluğu, mühendisliği, paraşütçülüğü vesaire 12 şubeyi ihtiva edecek şekilde Gök Üniversitesi tesis etmek. Sonra .... Şu çayırın bir kenarında, muradina ermiş insanların huzur ve saadetiyle oturup kahvemi içerken, bir işaretle yüzlerce tayyarenin birden havalandığını görmek" cevabın vermiştii ${ }^{42}$. Bütün gayret ve çalışmalarına rağmen bu arzusu gerçekleşmemiştir.

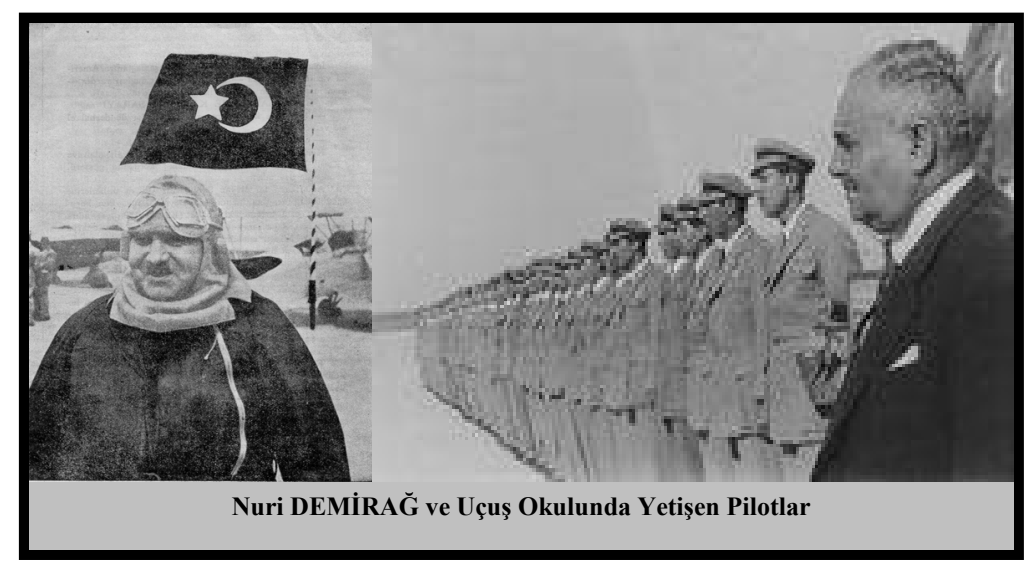

28 Eylül 1942 yılında Preveze Deniz Zaferi'nin 404'üncü kutlamaları için Beşiktaş Barbaros Türbesi'nde bir tören yapılmış, bu törene Demirağ

\footnotetext{
${ }^{40} \mathrm{Bu}$ yıllarda Türk basınında havacılığa önem veren ve havacılığın gerekliliğine inanan bazı yazarlar bulunuyordu. Ziya Şakir, Fikret Arıt bunlardan bazılarıdır.

${ }_{41}$ Nuri Demirağ Gök Okulu'nda Yapılan Tören ve Havacılık Çalışmaları.

${ }^{42}$ Şakir, a.g.e., s.81; Dervişoğlu, a.g.e., s.90,91
} 
tesislerinde üretilen 9 uçak da havadan üçerli kol halinde gösteri yaparak katılmıştır. Bu dönem Avrupa'da harbin kıyasıya devam ettiği hatta Türkiye'nin de zorlanarak harbe sokulmak istendiği zorlu günlerdir. Böyle bir ortamda milli imkanlarla yapılan uçak üretimi Türk milleti adına tarif edilemez bir gurur kaynağ 1 olmuştur. 1939 y1lında önemli gelişmelerin biri ise Demirağ'in yoğun israr ve gayreti ile Yüksek Mühendis Mektebi (İTÜ) Makine Şubesi Bölümünde, uçak mühendisi yetiştirmek üzere bir tayyare şubesi kurulması çalışmasına başlanmıştı ${ }^{43}$. Bu okula kendi oğullarını mühendis yetişmeleri için kayıt ettirirken kızlarının da buradan mezun olan mühendislerle evlenmelerini istemiştir ${ }^{44}$.

Ailesinin de havacılığın içinde yer almasına çalışırken, havacılığın riskli yönünü hiç dikkate almamıştır. Uçak Bölümü açılması o gün için oldukça ileri bir adımdır. Demirağ'ın da ısrarla üzerinde durduğu ve eksikliğini dile getirdiği bir diğer önemli konu olan, Türk Uçak Mühendisi yetiştirilmesine olan ihtiyaç 1941 yılında Türk Hava Kurumu tarafından da Başbakanlığa teklif edilmiştir. Teklif makul görülmüş ve teklif için ilgili bakanlıklarca çalışma başlatılmıştır. Başbakanlık tarafından verilen cavapta, çalışmanın yürütülmesi için Türk Hava Kurumu ile koordine edilmesi istenmiştir ${ }^{45}$. Demirağ'ın çok önceden gördüğü bir eksikliğin giderilmesi şüphesiz ülkeye önemli fayda sağlamıştır.

\section{c. Nuri Demiră̆’’n Ortağı Selahattin Alan}

Nuri Demirağ, uzun incelemeler sonunda büyük yatırımlar yaparak uçak fabrikası kurmuştur. Kurduğu uçak fabrikasının üretimi için uçağa ihtiyacı olan kurum ve kuruluşların doğal olarak uçak siparişi vermesini beklemiştir. Hava Sanayii gibi önemli ve pahalı bir sahada devlet desteği olması yadsınamaz. Çünkü, uçak sanayii çok pahalı ve teknolojinin en son yeniliklerini içermesi yanında devlet genelde tek ve ilk müşteridir. Nitekim ilk siparişler Türk Hava Kurumu tarafindan verilmiştir. Nuri Demirağ uçak fabrikasını kurmuş ve işi ehline bırakmıştır.

Demirağ, dönemin önemli uçak mühendislerinden olan Selahattin Alan ile ortaklık kurmuş, yönetimde ortağına her türlü esnekliği sağlamıştır. Selahattin Alan, Fransa'da eğitim almış, bilgili, ülkesi için birşeyler yapmak isteyen birisidir. Eskişehir'de Askeri Uçak Fabrikası'nda çalışmış ve mesleğinde temayüz etmiştî ${ }^{46}$. Burada çalışırken bir prototip uçak imalatı üzerinde çalışmış ancak istediği sonucu alamamıştır. Selahattin Alan,

\footnotetext{
${ }^{43}$ Tayhani, a.g.e., s.231

${ }_{45}^{44}$ Dervişoğlu, a.g.e., s.103-106

${ }^{45} B C A$, Tarih 10.06.1941, Dosya: 62100, Fon Kodu: 030.10, Yer No:61.409.15

${ }^{46}$ Adıgüzel, Türk Havacılığında İz, s. 207-211; Şakir, a.g.e., s.107,108; Tayhani, a.g.e., s. 111
} 
Demirağ ile beraber çalışmaya başladıktan sonra yalnız fabrika ile değil aynı zamanda Yeşilköy Gök Okulu ile de ilgilenmiştir. Üretimi yapılacak uçağın bilgilerini yakınen takip etmiş, uçağın çalışma standartlarını ortaya koymak, gerektiğinde prototip üzerinde hataları bizzat bulup düzeltebilmek maksadıyla pilotaj eğitimi de olduğundan, bizzat test uçuşlarını yapmıştır. Selahattin Alan'ın çalışmaları sonucu Nu.D.36 uçağı tamamlanmıştır. Diğer bir proje de Nu.D.38 tipi uçaktır. Alan'ın ansızın vefatı ile bu proje yarım kalmış, ancak daha sonra tamamlanmıştır ${ }^{47}$.

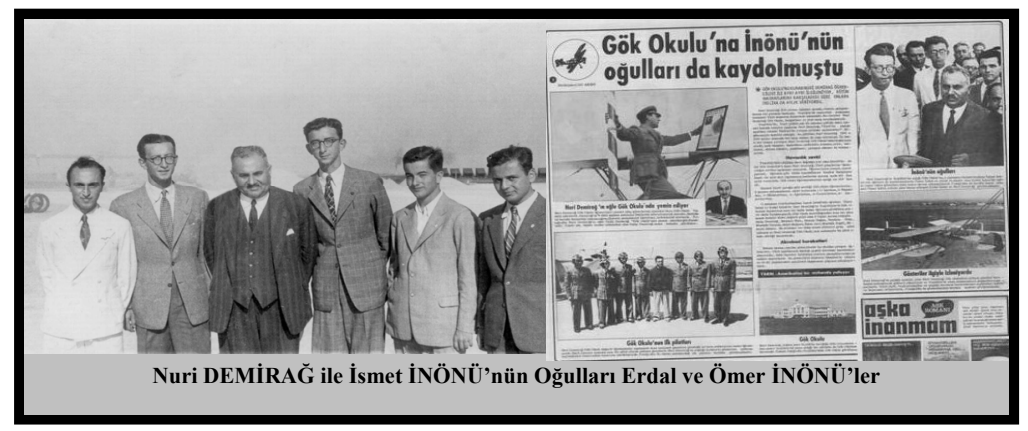

İmal edilen ND-36 (Al-2) tipi uçağı, Eskişehir'de yapılacak olan tanıtımında iniş esnasında pistin girişindeki su tahliye çukuruna girmiş ve uçak kaza-kırım geçirmiştir. Uçağın pilotu Selahattin Alan şehit olmuştur. Bu gelişme Türk Hava Kurumu ile Nuri Demirağ' $1 n$ ileride mahkemelik olmasına neden olmuştur. Daha sonra imalatı tamamlanan Nu.D.38 uçağına Havayolları tarafindan ilgi gösterilmemesi, şirkete ikinci önemli darbe olmuştur. $\mathrm{Bu}$ olumsuz gelişmeler sonrasında, Nuri Demirağ'ın hukuk mücadelesi başlamıştır ${ }^{48}$.

Demirağ'ın çalışmasına, müşteri olması ümit edilen kurumlardan sipariş gelmemesi nedeniyle devam edilememiş ve üretime geçilememiştir. Yeşilköy'deki Nuri Demirağ'a ait tesislerin havaalanı yapılmak üzere kamulaştırılması üzerine tam meyvesi toplanacak bir zamanda uçak üretim serüveni iflasla sonlanmıştır ${ }^{49}$. TOMTAŞ (Kayseri Uçak Fabrikası) ve Vecihi HÜRKUŞ'un çalışmalarında yaşanan sahne bir kez de Nuri Demirağ' da yaşanmıştır. Peki bütün çalışmaların aynı şekilde sonuçlanması bir tesadüf müdür?

\footnotetext{
${ }^{47}$ Hürkuş, Bir Tayyarecinin Anılarl, s.320-325; Adıgüzel, Türk Havacılığında İz., s. 210

${ }^{48}$ Dervişoğlu, a.g.e., s.106; Adıgüzel, Türk Havacılığında İz., s.207-209; Tayhani, a.g.e., $\mathrm{s} .230$

${ }^{49}$ Tayhani, a.g.e., s.231; Adıgüzel, Türk Havacılı̆̆ında İz., s.209
} 


\section{ç. Uçakların Muayenede Ret Edilmesi ve Demirăg'ın Cumhurbaşkanı'na Mektup Yazmast}

Türk Hava Kurumu tarafından Nuri Demirağ Uçak Fabrikasına verilen 65 adet planörün kabulü yapılmış, ancak üretilen ve test denemeleri yapılan uçakların, teknik şartnamede belirtilen motor özelliklerinin bire bir tutmaması nedeniyle kabulü yapılmamıştır. Bunda Selahattin Alan'ın, uçağı test ve muayene için geldiği zaman bir kaza sonucu hayatını kaybetmesi ve uçaklara olan güvenin sarsılması önemli rol oynamıştır. Ancak üretimi tamamlanan uçaklar daha sonra deneme testlerinden başarıyla geçmiştir. Bilirkişi raporları Demirağ lehinde karar vermişse de mahkeme süreci Demirağ' $ı$ aleyhine sonuçlanmıştır.

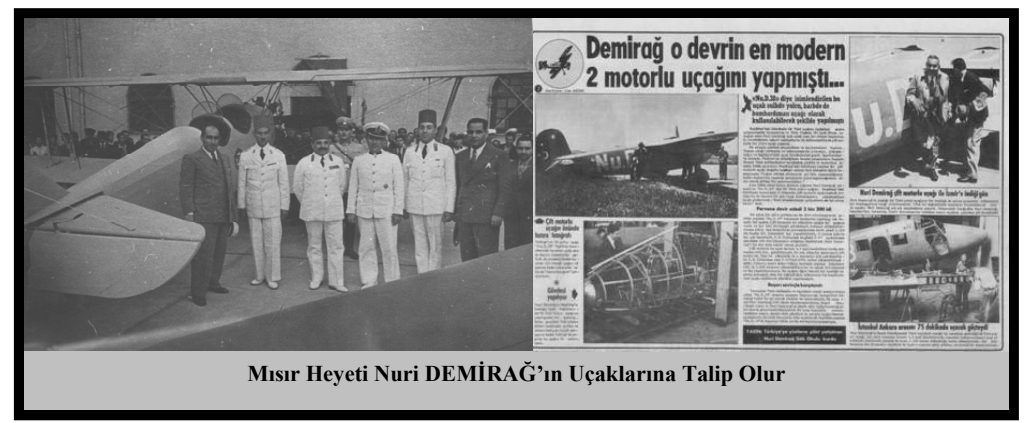

Bu konuda, Türk Hava Kurumu çalışanlarından Bahattin Adıgüzel'in havacılık tarihine 1şık tutan çalışmaları oldukça faydalı bilgiler vermektedir. Adıgüzel çalışmalarında, Türk tipi uçakların üretiminde çalışan ve o günlere ait hatıralarını dinlediği Uçak Mühendisi Şükrü Er, Mehmet Kum, Türk Hava Kurumu'nda yönetici olarak veya pilot olarak görev almış olan Cemal Uygun, Korkut Efe, Mustafa Ataylar'nn kanaatlerini aktarmaktadır.

Nuri Demirağ'ın uçağının Türk Hava Kurumu tarafından ret edilmesine dair Mehmet Kum: "Aslında teknik şartname gerekleri Kurum'un aleyhine değil, lehine olabilecek bir uyumsuzluktu. Yani, örneğin şartname, pervanenin 1850 devirde motor gücü 165 beygir olması gerekirken, imalatçı firma teknik yazll verilerinde bu gücün 1785 devirde 150 beygir olduğunu yazmıştı. Oysa bu motorun pervane devri 1850'ye çıkartıldığında motor gücü 174 beygir olduğu görülmekteydi. Bu da teknik şartname limitleri içerisinde olan bir şeydir. Motor imalatı yurt dışında yapıldiğı için olduğu gibi satın alınmış. Istenen standartlara en yakın motor olarak da o günün şartlarında bu motor varmış. Ama uçă̆ın diğer dizaynı tamamen Nuri Demirağ Fabrikasında yapılmaktaydl. Dizayn ile ilgili olarak teknik şartnameye uymayan bir şey tespit edilemedi. Dolaylsyla bir milli serveti batıracak nitelikte, teknik şartnamede uyumsuzluk yoktu" açılamasını 
yapmıştır $^{50}$. Benim de (Osman YALÇIN) 2007 yılında evinde görüştüğüm, Türk Hava Kurumu'nun uçak üretim tesisinde ustabaşı olarak çalışan (2008 yılı vefat etmiştir) 82 yaşındaki Ahmet Duygu benzer şeyleri söylemiştir ${ }^{51}$. Maalesef büyük gayretlerle Atatürk'ün hedefini yakalamak için yapılan çalışmaların sonucu alınamamıştır.

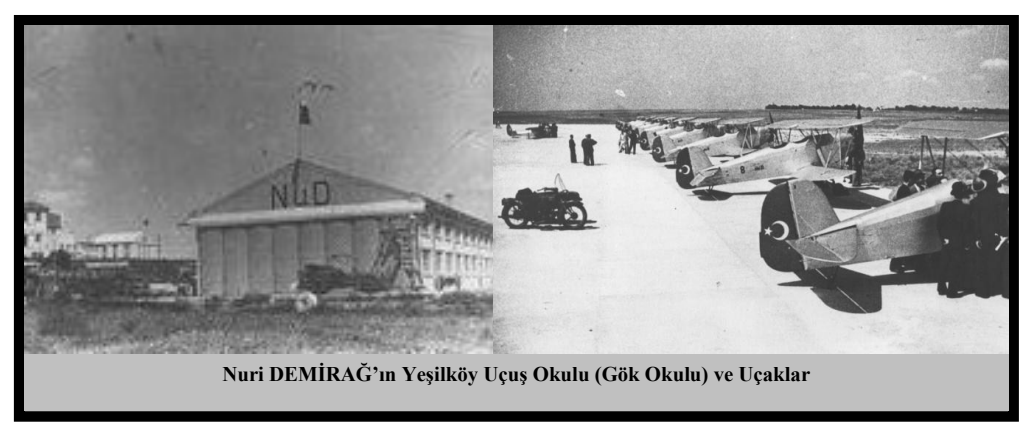

Nuri Demirağ, şüphesiz Türk Hava Kurumu'nun ülkeye yaptı̆̆ 1 hizmetlerin farkındadır. Son ana kadar konunun taraflar arasında görüşmeler yolu ile çözümlenmesi taraftarıdır. Sonuç alınamadığı için hukuki sürece başvurmuştur. Aslında sorun uçağın motorundan kaynaklanmaktadır. Yukarıda Mehmet Kum'un açıklamasında görüldüğü gibi ithal edilen motor şartnamede belirtilen kıstaslarla birebir uyuşmamaktadır. $\mathrm{Bu}$ sorunlar mahkemeye intikal etmiş ve yargı kararını Demirağ aleyhine vermiştir. Bu durum yine de Demirağ' 1 idealinden vazgeçirmemiştir. Uçak imalatına yönelik iddiası devam etmiş ve 1944 yılında Nu.D-38'in imalatı tamamlanmıştır. Uçağın teknik özellikleri: 6 kişilik, çift kumandalı, 2200 devirli 2 adet 160 beygir gücünde motorla donatılmış ve saatte $325 \mathrm{~km}$ sürat yapmaktadır. Boş ağırlığ $1200 \mathrm{~kg}$. dolu ağırlığı ise $1900 \mathrm{~kg}$.dır. Tam depo yakıt ile $1000 \mathrm{Km}$. menzile sahiptir. 3,5 saat havada kalabilmektedir. Tavan irtifas1 5500 metredir. Tayyarenin modeli Türk mühendisler tarafından çizilmiş, motorlar hariç tüm aksam Türk teknisyen ve işçisinin ürünüdür. Çalışmamızda daha önce belirtildiği gibi bu uçağın devlet hava yolları tarafindan kabul edilmesi beklenmekteydi ama bu da gerçekleşmemiştir. Test uçuşları başarı ile tamamlanmıştır. Nitekim Nu.D-38 tipi uçak 26 Mayıs 1944 tarihinde İstanbulAnkara seferine başlamıştır. Uçağı Ankara'da Devlet Hava Yolları Genel Müdürü Ferruh Bey ile orada tesadüfen bulunan ve uçak tasarımı üzerine uzman olan bir Amerikalı karşılamıştır ${ }^{52}$.

\footnotetext{
${ }_{51}^{50}$ Adıgüzel, Türk Havacılı̆̆ında İz., s.148

${ }^{51} 2007$ y1l Ocak ayında Ahmet DUYGU ile Osman YALÇIN'ın Sincan'da, Ahmet Duygu'nun evinde yaptığ görüssme.

52 Adıüzel, Türk Havacılı̆̆ında İz., s.149-151
} 
Nuri Demirağ'a göre havacılık; son derece yüksek teknolojiyi gerektiren, milli ve stratejik önemi olan bir sahadır. Tek başına ve sınırlı imkânlarla başarıyı yakalamak mümkün değildir. Ancak Türkiye Cumhuriyeti Devleti'nin kurumlarının milli kaynaklarla üretilen Türk tasarımı uçaklara ihtiyacı kaçınılmazdır.

Nuri Demirăg, uçak üretmek için fabrika kurmaya ve uçuş okulu açmaya başlarken kendisine öngörülü yöneticiler destek vermiştir. Ancak yatırımların yapılmasına rağmen fabrikaya kurum ve kuruluşlardan iş verilmemesi işadamını zora sokmuştur. Yaklaşık 1,5 milyon Türk Lirası harcayarak ortaya koyduğu eserin heder olmaması için 29 Kasım 1939 ve 26 Ağustos 1940 tarihinde de iki defa dönemin Cumhurbaşkanı İsmet İnönü’ye mektup yazmıştır.

Gerek medeni cesaretini ortaya koyma, gerekse uzağ 1 görme mevzuunda başı başına tarihi bir vesika olan bu mektuplarda özetle aşağıda değinilen hususlara yer verilir. Birinci mektupta aşağıda belirtilen hususlar yer alır ${ }^{53}$.

a. Göklerine hakim olmayan milletlerin yerlerde sürüneceğine; daha doğrusu yerin dibinde çürüyeceğine inandığını belirtir ve buradan hareketle, 1936 yllında memleketin ihtiyacına tamamen cevap verecek büyük bir tayyare endüstrisi kurmak tasavvurunda bulunur ve Genelkurmay Başkanı Mareşal Fevzi Çakmak kendisine destek verir.

b. Beşiktaş'ta kurduğu tayyare atölyesiyle, Yeşilköy'de yapmakta olduğu modern uçuş meydanı, tamir atölyesi ve hangara ait plan ve krokiler ile Divriği'de kurulacak esas fabrikaya ait planlar ve su kuvvetlerinden elektrik istihsali için değirmen ve baraj mahali krokileri mektupta Cumhurbaşkanına sunulur.

c. Uçuş Okuluna insan kaynağ yetiştirmek için yaptırdığ 1250 mevcutlu orta mektebe ait fotoğraflar mektuba ilişik olarak eklenir.

ç. Yetkili makamlarca Beşiktaş’taki atölyenin yıllık imalat kabiliyetinin bildirilmesi isteğine; y1llık 300 mektep veya 150 eğitim veya 50 avc1 tayyaresi yapabileceği cevabını verir.

d. Hava Kurumu'nun verdiği 65 planör kuruma teslim edildiği ve 10 mektep tayyaresi ile ilgili yaşanan süreç ve kendisine yapılan haksızlıklar anlat $11 r^{54}$. Konu ile ilgili, Hava Kuvvetleri teknik komisyonu tarafindan ilk Türk tipi olan tayyareye ait sandıklar dolusu yüzlerce aerodinamik ve statik

\footnotetext{
${ }^{53} B C A$, Tarih 29.11.1939, Dosya: 6158, Fon Kodu: 030.10, Yer No: 59.399.25; Dervişoğlu, a.g.e., s.116, 211-218

${ }_{54}$ Uçak miktarı bazı yerlerde 12 bazı yerlerde 10 adet olarak geçmektedir.
} 
resimleri ve hesapları mezkûr komisyonca aylarca tetkik ve performans tecrübeleri yapılarak mükemmel, normal bir mektep tayyaresi olduğunun teyit edildiği belirtilir. Kurulun, Hava Kurumu'na tebliğ ve uçuş müsaadesini verdiği ancak Hava Kurumu'nun memlekete yegane salahiyettar bu fen komisyonunun kararını dinlemeyerek tayyareleri kabulden imtina ettiği belirtilir. Hava Kurumu'nun, 10 uçağ 1 almamakta 1srar ile teminat mektubu olan 14.000 lirayı zapt ve avans verdikleri 40.000 lira istirdat ettiği belirtilir.

e. İşçilerin ve fabrika personelinin işsiz kaldığı, esasen 1939 yılına kadar da tam ve kâmil bir mesai sahası da bulunamadığı, uçak fabrikası için toplamda bir buçuk milyon lira harcadığ apartman yaptırabileceği ve senede 150-200 bin lira kazanç elde ederek oldukça kazançlı çıkabilecekken, karakterinin buna müsait olmadığı ifade edilir.

f. Türk'e ecdadından miras ve dünyaya numune-i imtisal olmuş olan sipahiliğin, süvariliğin, serdengeçtiliğin bugünkü şeklinin tayyarecilik olduğu belirtilir. Havacılığın önemine vurgu yapılarak, istenildiği takdirde gece, gündüz, kış, yaz, yağmur, çamur, kar, bora; firtına manialarını bertaraf edecek, vatanın her bucağında şimdilik en az 60-70 yerinde modern uçuş meydanları ve yanı başında tamir atölyeleri, hangarlar, farklı sınıf ve derecelerde hava mektepleri ve birkaç yerde tayyare ve motor fabrikaları yapılarak havacılığa yüzlerce, binlerce, on binlerce ihtiyat, yapıcı, uçucu yaratıcı elemanlar ve vesait yetiştirmenin mümkün olduğu belirtilir.

g. Havacılığın hızla geliştiği ve gelişmeye devam ettiği gerçeğinden hareketle; havacılık işlerinin düzenlenmesi için bu gün (1939) hepsi aynı rütbede işlerle görevli hava komutanlarının başlarına tepeden tırnağa, başından sonuna kadar mesuliyeti nefsinde toplayan yırtıcı, yaratıcı bir şahsiyetin (her memlekette olduğu gibi) geçirilmesi ve havacıllı̆̆ın düzenlenmesinin gerekliliğine inandığını belirterek birinci mektubunu tamamlar.

Nuri Demirağ'ın devrin Cumhurbaşkanı İsmet İnönü'ye yazdığ ikinci mektubun tarihi 26 Ağustos 1940'dır. Mektuptan anlaşıldığına göre Cumhurbaşkanı tarafindan daha önce kabul edilmiş ve bir görüşme yapılmıştır. İkinci mektubunda temas ettiği konular özetle şöyledir ${ }^{55}$;

a. Kabulde konuşulan hava sanayii kurma ve personel yetiştirilmesi konuları hatırlatılır ve birinci mektup ikinci mektubun ekinde yeniden gönderilir.

55 Dervişoğlu, a.g.e., s.116, 211-218; Deliorman, a.g.e., s.38; Dervişoğlu, a.g.e., s.Ekler 
b. Almanya tayyare, tank ve teferruatına ait gerekli ham maddelerin çoğunu ithal ederken, Türkiye'nin bu ham maddelere sahip olduğu ve bunların mamul hale getirilerek yeteri kadarının kullanılırken bir kısmı ile ülkeye döviz kazanılabileceği belirtilir.

c. Görüşmede Cumhurbaşkanı'nın nasıl yardım edebileceği sorusuna, yardımın şeklini düşüneceğini ve bilahare bildireceğinden bahisle, elindeki 10-12 mektep tayyaresinin ve birkaç planörün Hava Kuvvetlerince veya Türk Kuşunca satın alınması gibi mevzii yardımların düşman şerrinden vatanı muhafaza için yapılmak istenen asli hizmetlere zerre kadar tesiri olamayacağı, bu nokta üzerinde hiçbir isteği bulunmadığını belirtir.

ç. Bütün yedek malzemeleri ve donanımıyla dönemin Alman tayyare, tank ve askeri kamyonları ve uçucu ve yapıcı personelleri adedinden bir tane bile eksik olmamak ve vasıfça bunların çok üstünde bulunmak üzere azami 7-8 sene zarfında Türkiye'de aynı sistemlerin üretilmesinin mümkün olduğu ve bunun vergiden muaf olmak kaydıyla oldukça cüzi bir miktara yapılabileceği iddiasına yer verilir. Devletin mevzuatı gereği bunun onda birinin vücuda getirilmesine imkân olmadığı gibi on misli para da sarf edilse yine maksadın sağlanamayacağı ifade edilir.

d. Emir verilmesi halinde yaptı̆̆ 1 her işin hesabını vermek kaydıyla, yanına havacılık eğitimi alan gençleri de alarak dönemin tanınmış Amerikalı Profesör Gasner'le birlikte satın alacağı teçhizatı getirerek harp sanayii tesislerini kurarak faaliyete başlayabileceğini belirtir.

e. Destek verilmesi halinde bu desteğin gizli kalması aksi halde çalışma arkadaşlarının devlet desteği olduğunu bilirlerse suiistimaller olabileceğinden endişe ettiğini belirtir.

f. İkinci Dünya Savaşı'nın başından beri devam eden muharebelerin hiçbirinde süngü süngüye harp edilmediğinden hareketle, Türkiye'nin savunulması için düşmanların silahlarından daha üstün araçlarla Türk dehasının mahsulü olan yeni icatların, gerektiğinde dünyaya karşı koymaktan asla çekinmeyen kahraman Türk askerlerini teçhiz etmenin devleti idare edenlerin görevi olduğu hatırlatılır.

g. Müsaade edilmesi halinde kurulan bütün fabrika, levazım, makine, alet, edevat ve bilumum tesisat ve madenlerin devlete devredileceği ve kendisinin çorbada birazcık tuzu bulunmuş olmakla bahtiyar olacağını ifade eder. Mevcut yap1 ile Türkiye'nin savunmasının mümkün olmayacağını belirterek milyonlarca insanın korunması için milyarlarca paranın harcanmasından kaçınılmamasın ister ve isteklerinin karşılanması 
durumunda ülkenin müdafaasına hizmet edileceğini içeren ikinci mektubu sona erer.

Demirağ'ın yapacağı yatırımlarda Almanya'yı örnek aldığı dikkate alındığında Türkiye için 35.000 uçak, 12.000 tank üretilmesi, 150.000 pilot

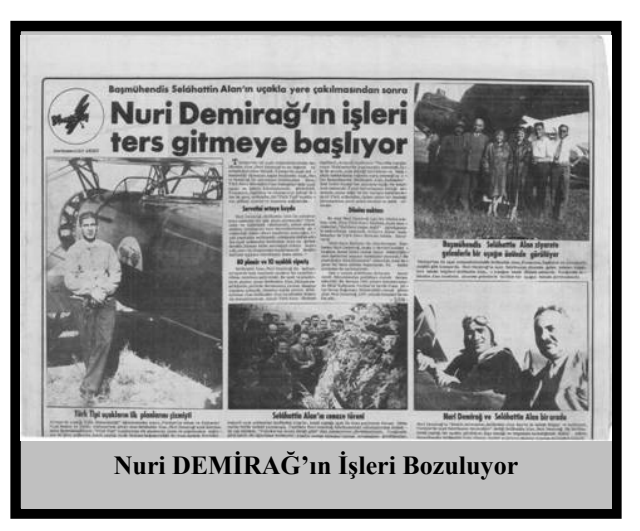
yetiștirilmesi, 68.000 kamyon imalatı ve 200.000 yapicı eleman yetiştirilmesini içermektedir ${ }^{56}$.

Bu idealist yaklaşımı bir hayal olarak nitelemek doğru olmayacaktır. Çünkü girişimci Nuri Demirağ, başta demiryolu ve uçak fabrikası çalışmalarında olduğu gibi hayatının pek çok döneminde başarılması oldukça zor olan işleri başarıyla tamamlamış ve zor işleri gerçekleştireceğini ispatlamıştır. Bununla birlikte yukarıda miktarları verilen sistemlerin üretilmesi ve milli imkânlarla sağlanması pek olası gözükmemektedir. Her şeye rağmen gerekli destek verilseydi Türkiye'de hava harp sanayiinin milli imkânlara dayalı olarak kurulmasının mümkün olacağı görülmektedir.

Nuri Demirağ'ın hukuk mücadelesi devam ederken bazı vatandaşlar da konuya taraf olmuş ve Nuri Demirağ'a destek vermiştir. İskenderun'dan Doktor Nedim Cankat isimli bir vatandaş, 10 Nisan 1948 tarihinde ikinci Cumhurbaşkanı İsmet İnönü’ye çektiği açık telgrafta, incelemelerde bulunduğu Demirağ'ın uçak üretim tesislerinin, ülke için önemine ve ülkeye olan katkısına değinerek çirkin saldırılar karşısında destek verilmesini talep etmiştir $^{57}$. Konu ile ilgili Milli Savunma Bakanlığg Hava Müsteşarlığ 1 tarafindan yapılan açıklamada, Nuri Demirağ' in Milli Savunma Bakanlığı ile esaslı bir görüş teatisinde bulunmadan büyük masraflarla bir uçak fabrikası kurduğunu ve üretilen uçaklara Milli Savunma Bakanlığı tarafından uçuş müsaadesinin verildiğini ancak üretilen uçağın hava ordusunun ihtiyacını görecek evsafta olmadığına dikkat çekilmektedir. Arşiv belgesinin devamında, 1940 yılında bahsi geçen fabrikaya bir tip uçağın onarımı ile muhtelif yedek parça siparişi verildiği belirtilir. Mevcut durumda ise fabrikada bulunan tesisat ve teçhizatın Hava Kuvvetleri fabrikalarında olması nedeniyle buradan istifade yoluna ihtiyaç duyulmadığı bilgisi Başbakanlığa bildirilirr ${ }^{58}$.

\footnotetext{
${ }_{57}^{56}$ Dervişoğlu, a.g.e., s.216-218

${ }^{57} B C A$, Tarih 28.6.1948, Dosya: 6380, Fon Kodu: 030.10, Yer No: 61.413.34; Dervişoğlu, a.g.e., s.118,119

${ }_{58}$ BCA, Tarih 28.6.1948, Dosya: 6380, Fon Kodu: 030.10, Yer No: 61.413 .34
} 
Nuri Demirağ' 1 Hava Harp Sanayii kurma gayret ve mücadelesi, ne yazık ki başarısızlıkla sonuçlanmıştır. Demirağ'ın uçaklarının Hava Kurumu tarafindan alınmaması üzerine imal edilen uçakların bir kısmı Gök Okulu'nun pilotlarının eğitiminde kullanılmış, bir kısmına ise İspanyollar talip olmuştur. Ne var ki, anlaşılması güç nedenlerle satılmasına müsaade edilmemiştir.

Anlaşıldığına göre Demiră̆’ın uçakları siyasi çekememezliğe kurban gitmiştir. İran ve Irak uçaklara talip olmuş, “yakarız ama yine de sattırmayız” gibi bugün için çok anlamsız bir tepki ile satışa müsaade edilmemiştir ${ }^{59}$. Uçaklar uzun yıllar Yeşilköy hangarında bekletilmiştir. Dönemin Hava Kuvvetleri Komutanın müzeye koydurmak için harekete geçmiş ancak kısa bir süre önce hurdacıya satıldığı söylenmiş ve bu girişim de sonuçsuz kalmıştı́ ${ }^{60}$.

Bugün Nuri Demirağ'ın Uçuş Okulunun yerinde Atatürk Havalimanı yer almaktadır. Nuri Demirağ, Hava Harp Sanayii alanında karşılaştığı talihsiz gelişmelerden sonra nakliyecilik alanında çalışmalarını sürdürmüştür. Bir dönem siyasi hayata atılmış ve çok partili hayata geçişte ilk muhalefet partisi olan Milli Kalkınma Partisi'ni kurmuştur. Siyasi hayatta da gerekli ilgiyi görmeyen partisi Türk siyasi hayatında tutunamamıştır. Hatta toplantılarda kuzu ziyafeti verildiğinden rakipleri tarafından Milli Kalkınma Partisi'ne, "Kuzu Partisi” yakıştırması yapılmıştır. 1954 seçimlerinde Demokrat Parti listesinden milletvekili seçilmiş ve 1957 yılında şeker hastalığından vefat etmiştir.

\section{SONUÇ}

Günümüzde dünyada güçlü ülke olmanın önemli bir unsuru milli imkânlarla beslenen, diğer ülkelerle rekabet edebilen ve teknolojiyi yakalayan hava harp sanayiidir. Milli çıarların korunmasında askeri havacılık ve hava sanayii önemini korumaktadır Nitekim Türkiye bu gerçeği yıllar önce görmüş ve bu alanda bir takım çalışmalar yapılmıştır.

Türkiye Cumhuriyeti'ni kuran kuşak büyük umutlarla yola çıkmıştır. Hemen herkesin gönlünde bir devri inşa etme ve dünyada güven duyulan gelişmiş bir Türkiye'nin meydana getirilmesi heyecanı vardı. Bu öyle bir coşkudur ki, karasabanın arkasındaki Anadolu insanı ile Çankaya'dan ülkesini inşa etmekte olan Atatürk'ün hedefleri aslında pek de farklı değildir. $\mathrm{Bu}$ yüksek hedefi sanayii alanında da görmekteyiz. Nuri Demirăg, Selahaddin Alan ile beraber ürettikleri Nu.D.36 uçağı İngiltere'de

\footnotetext{
${ }^{59}$ Tuncay Deniz, Türk Uçak Üretimi-Turkish Aircraft Production, 2004, Türkiye, s.31

${ }^{60}$ Dervişoğlu, a.g.e., s. 117
} 
yayımlanan ve dünyanın tek havacılık katoloğu olan 1949 yılı baskısında yer almıştır $^{61}$. Ne var ki, bu süreç 1940 sonrası yaşanan iç ve dış gelişmeler ile hızını kaybetmiştir.

Vecihi Hürkuş, Nuri Demirağ, Selahattin Alan ve bağış uçakları kampanyası ile Türk milletinin destek verdiği havacılık alanında güçlü ve milli uçak üretme projeleri sürdürülememiştir. Oysa aynı yıllarda Amerikan Hükümeti girişimcilere destek olmuş ve havacılıkta dünya devi olmuştur. Howard Hugs'un devletten aldığı destek 60 milyon dolardır. Bu süreçte Türk Hava Kuvvetleri de muhtelif raporlarla Türk tasarımı uçaklara olan ihtiyacı defalarca gündeme getirmiştir.

Demirağ varlıklı, sebat etmesini bilen, girişimci bir müteşebbistir. Ne var ki, hava harp sanayii, çok büyük öngörüsü olsa bile, bir kişiyle varlık bulacak bir saha değildir. Havacılıkla ilgisi bulunan kurum ve kişilerin milli uçak üretme gayretlerine taraf olması gerekirdi. Demirağ'ın bir kaç kişi dışında destekçisinin olmaması sıkıntının temel nedeni olmuştur. Hatta sık sık yakınlarına dünyaya 30 yıl erken geldiğini söylemesi de bunu teyit etmektedir. Devletin politikası olması gereken hava harp sanayii özel girişimcilerin de olmasına rağmen destek görmemiştir.

Türkiye'de demiryolları inşaatı, hava harp sanayii, ticaret ve siyaset alanında önemli bir yeri olan Nuri Demirağ, Türkiye'nin en sıkıntılı zamanında yaşamıştır. Türkiye Cumhuriyeti'ne; ticari, sanayii ve siyasi sahada hizmet etmiştir. Milletten kazandığını milletin en zayıf ama hayati açıdan önemli olan Demiryolu ve Hava Harp Sanayiine yatırım olarak dönüştürmüştür. Nuri Demirağ, bu yolda engellemelerle karşılaşmış ve sıkıntılar çekmiştir. Büyük yatırımlarla kurmuş olduğu fabrikanın batma noktasına gelmesi ile hukuk mücadelesi vermiş, bütün engellemeler rağmen mücadelesini sürdürmüştür.

Nuri Demirağ döneminin ilmi ve edebi şahsiyetleriyle ilgilenmiştir. Türk edebiyatında yer alan önemli şahsiyetlerleri evinde ağırlamış, iltifat etmiştir.

${ }^{61}$ Bora Çağlar, Havacılık ve Savunma Sanayi Üzerine Çalışmalar, HAVELSAN, Ankara, 2000, s.241 


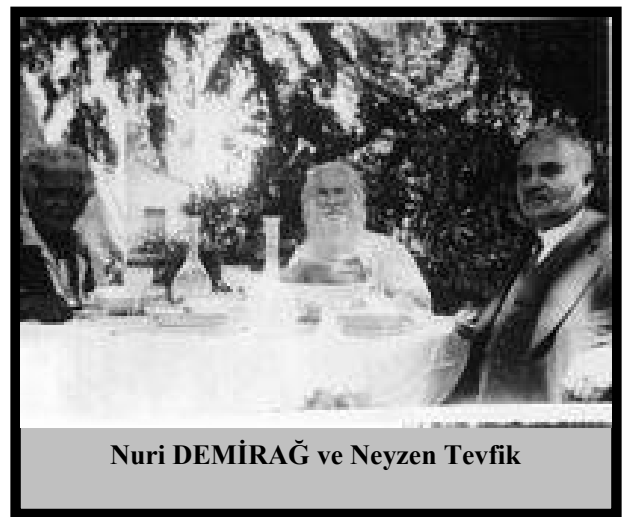

Bugün de Demirağ'ın çalışmalarına benzer girişimler o günkü kadar önemlidir. Hatta havacılıkta yaşanan hızlı gelişmeler konuyu daha da önemli hale getirmektedir. Ülkelerin varlığını hür ve onurlu bir şekilde sürdürmeleri için havacılığın gerekliliği son $10-15$ yılda defalarca görülmüştür. 11 Eylül saldırısı, Afganistan, Bosna-Hersek ve Irak ve Ürdün'de yaşanan talihsiz gelişmeler hava gücünün ihmal edilemeyeceğinin ifadesi olmuştur.

Daha önce ifade edildiği gibi Nuri Demirağ ile Atatürk'ün havacılık hakkındaki öngörüleri arasında büyük benzerlikler bulunmaktadır. Demirağ'ın, "Zafer artık süngünün ucunda değil uçakların kanatlarındadır." sözü ile Atatürk'ün "Bundan sonrası için, bütün tayyarelerimizin ve motorlarını memleketimizde yapılmasl ve hava harp sanayiimizin de bu esasa göre inkişaf ettirilmesi iktiza eder. Hava Kuvvetlerinin aldı̆̆ ehemmiyeti göz önünde tutarak bu mesaiyi planlaştırmak ve bu mevzuu layık olduğu ehemmiyetle milletin nazarında canl tutmak lazımdır"" . "Göklerde bizi bekleyen yerimizi almak zorundayız. Yoksa o yeri başkaları istila eder ve işte o zaman bu ülke ve ulus elden gider ${ }^{63}$." sözleri söylendiği zaman kadar bugün de halen önemli ve anlamlidir.

\section{KAYNAKLAR}

Atatürkçülük Atatürk'ün Görüş ve Direktifleri Birinci Kitap, Gnkur. Bsm., Ankara, 1983.

ADIGÜZEL, M. Bahattin, Türk Havacıllğında İz Bırakanlar, THK Kültür Yay. No:7, Ankara, 2006.

DERVIŞOĞLU, Fatih M., Nuri Demirăg Türkiye'nin Havacllık Efsanesi, Ötüken Neş., İstanbul, 2007.

${ }^{62}$ Yaşar Özdemir, Atatürk ve Türk Havacılı̆̆ı, Hv.Bsm., Ankara,1981,s.48; Bora Çağlar, Havacılık ve Savunma Sanayi Üzerine Çalışmalar, HAVELSAN, Ankara, 2000, s.338,339

${ }^{3}$ Oktay Verel, Istikbal Göklerin Gökler Bizimdir C.I-II, Türk Hava Kurumu Yayınları 3, İstanbul, 1985, s.10 
Başbakanlık Cumhuriyet Arşivi (BCA), Tarih 28.6.1948, Dosya: 6380, Fon Kodu: 030.10, Yer No: 61.413.34

$B C A$, Tarih 27.11.1939, Dosya: 25712, Fon Kodu: 030.10, Yer No: 212.441.12

$B C A$, Tarih 29.11.1939, Dosya: 6158, Fon Kodu: 030.10, Yer No: 59.399.25

$B C A$, Tarih 10.06.1941, Dosya: 62100, Fon Kodu: 030.10, Yer No:61.409.15

$B C A$, Tarih 29.11.1939, Dosya : 6158, Fon Kodu: 030.10, Yer No: 59.399.25

$B C A$, Tarih 28.6.1948, Dosya: 6380, Fon Kodu: 030.10, Yer No: 61.413.34

ÇAĞLAR, Bora, Havacılık ve Savunma Sanayii Üzerine Çalışmalar, HAVELSAN, Ankara, 2000

DELIORMAN, M. Necmettin, Nuri Demirăg'ın Hayat ve Mücadeleleri, Nu.D.Matbaası, İstanbul, 1957

DENIZ, Tuncay, Türk Uçak Üretimi-Turkish Aircraft Production, 2004, Türkiye

İhsan, TAYHANI, Atatürk'ün Bağımsızlık Politikası ve Uçak Sanayii 19231950,Türk Hava Kurumu Basımevi, Ankara, 2001

ÖZDEMİR, Yaşar, Atatürk ve Türk Havacılı̆̆l, Hv.Bsm., Ankara,1981

ERDEM (Edt.), Tevfik, Feodaliteden Küreselleşmeye temel Kavram ve Süreçler, Lotus Yay., Ankara, 2006

ŞAKİR, Ziya, Nuri Demiră̆ Kimdir?, Kanaat Matbaası, İstanbul, 1947

VEREL, Oktay, Istikbal Göklerin Gökler Bizimdir Birinci Cilt, Türk Hava Kurumu Yayınları 3, İstanbul, 1985

YALÇIN, Soner, Efendi-Beyaz Türklerin Büyük Sırrl, 5. Bsk., İstanbul, 2004

YALÇIN, Osman, Türk Hava Kuvvetleri Teşkilatlanma Tarihi, G.Ü.Sos.Blm.Enst., Basılmamış Yüksek Lisans Tezi, Ankara, 2004

YALÇIN, Osman, Türk Hava Harp Sanayii Tarihi, G.Ü.Sos.Blm.Enst., Basılmamış Doktora Tezi, Ankara, 2008 